Journal of Applied Veterinary Sciences, 5 (3): 31 - 39 (2020).

ISSN: Online: 2090-3308, Print: 1687-4072

Journal homepage : https://javs.journals.ekb.eg

\title{
Antigenic and Genomic Characterization of Local Fowlpox Virus Isolate in 2017
}

\section{Aboul Soud, E. A ${ }^{1}$, Ayatollah, I. Ibrahim. ${ }^{1}$, Abd El-Moaty, D. A. M. ${ }^{{ }^{*}}$, Kafafy M. H. ${ }^{1}$ and} Abass. A. M. ${ }^{2}$

${ }^{1}$ Pox Vaccines Research Department, Veterinary Serum and Vaccine Research Institute (VSVRI), Agricultural

Research Center (ARC), El-Seka-El-Beda Street, Abbasia, Cairo, Egypt.

${ }^{2}$ Genetic Engineering Research Department, Veterinary Serum and Vaccine Research Institute (VSVRI), Agricultural Research Center (ARC), El-Seka-El-Beda Street, Abbasia, Cairo, Egypt.

*Corresponding Author, Dalia Ahmed M. Abd El-Moaty, E-mail: dody.ahmed@gmail.com

\begin{abstract}
This study presents a local isolate of fowl pox virus (FPV) isolated and propagated from backyard naturally infected laying hens in El-Sharkia Governorate, Egypt, during the period of January to November 2017. Isolation and propagation were carried out from collected skin lesions on the chorioallantoic membrane (CAM) and chicken embryo fibroblast (CEF) with obtained $4^{\text {th }}$ passage virus titers $4.0 \log _{10} \mathrm{EID}_{50} / \mathrm{ml}$ at the in CAM and $3.5 \log _{10} \mathrm{TCID}_{50} / \mathrm{ml}$ in CEF respectively. They showed characteristic pock lesions of FPV and cytopathic effect (CPE) of FPV at the $3^{\text {rd }}$ passage on CAM and CEF, respectively. Virus neutralization test (VNT) results confirmed that the obtained isolate is FPV. Molecular characterization of (Sharkia2017/VSVRI) was performed with Polymerase chain reaction (PCR) to amplify $578 \mathrm{bp}$ of $\mathrm{P} 4 \mathrm{~b}$ (fpv167) gene and $1150 \mathrm{bp}$ of fpv140 gene. Sequence and phylogenetic analysis of both genes confirmed the relatedness of (Sharkia2017/VSVRI) isolate to sub-clade A1 of fowl pox viruses with $99.7-100 \%$ identity to fowl pox virus sequences published in GenBank.This study reports the antigenic and genomic characterization of the locally isolated FPV (Sharkia2017/VSVRI) using VNT and PCR confirmed by sequence analysis to help in the production of FPV tissue culture vaccine from the obtained local FPV after confirming its immune response as a candidate vaccine.
\end{abstract}

Keywords: Fowlpox virus (FPV), fpv140, P4b (fpv167),Virus neutralization test (VNT).

J. Appl. Vet. Sci., 5(3): $31-39$.

\section{Original Article:}

DOI :HTTPS://DX.DOI.ORG/10.21608/JA VS.2020.98319

Received : 30 April, 2020.

Accepted: 09 June, 2020.

Published in July, 2020.

This is an open access article under the term of the Creative Commons Attribution 4.0 (CC-BY) International License. To view a copy of this license, visit

http://creativecommons.org/licenses/by/4.0/

\section{INTRODUCTION}

The Fowl pox virus (FPV) is a DNA virus that belongs to the family Poxviridae, subfamily Chordopoxvirinae, genus Avipoxvirus, in addition to pigeon pox virus (PPV) and turkey pox virus (TPV) (Andrew et al., 2012). The Fowl pox virus affects poultry and influences on egg production. The disease has two forms, the cutaneous nodular form (Dry form) that shows skin nodular lesions, especially on the thighs, eyelids, and combs, accompanied by low mortality. The diphtheritic form (Wet form) is characterized by respiratory symptoms such as sneezing, gasping, head-shaking with a higher mortality rate in young chicken (Masola et al., 2014).
Different clinical signs of pox virus are displayed in infected chicken. It depends on the route of transmission, the virulence of the virus strain and the host susceptibility (Offerman et al., 2013). The confirmative diagnosis is made by using one or a combination of these techniques: isolation of FPV in cell culture of avian origin, or the Chorio-Allantoic membrane (CAM) of embryonated chicken eggs (ECEs) (OIE, 2018). The Pock forming ability of FPV obtained from layer chicken was examined to describe the adaptation in CEF. The cytopathic effect (CPE) characterized by syncytia and plaque formation and cell aggregation (Gilhare et al., 2015). 
The viral inclusion bodies could be detected by staining of tissue specimen with Haematoxylin and Eosin to be examined by light microscope, or immune histochemical techniques (IHT) and fluorescent antibody (FA) and demonstration of viral particles with negative staining electron microscopy (Sawale $\boldsymbol{e t}$ al., 2012). Also, polymerase chain reaction ( $\mathrm{PCR}$ ) is used to detect the DNA of fowl pox virus in the infected tissue samples that could be confirmed by sequence analysis. Serological assays like the Serum Neutralization test can be used for confirmation of the Fowl pox virus (Das et al., 2013 and Nesma 2016).

FPV genome consists of a double-stranded DNA with a central coding region surrounded by two inverted terminal repeat regions identical to each other. The genome size is approximately $288 \mathrm{kbp}$ and encodes 260 open reading frames. The P4b protein gene of Avipox encodes a 75.2 k Da core protein and is usually used for comparative genetic identification. On the other hand, amplification of the AP-P4b by PCR was used for the detection of avian poxviruses (Manarolla et al., 2010). The phylogenetic analysis of (P4b) could classify APV into three clades; clade A (FPV), clade B (Canary pox virus), and clade C (Psittacine pox virus) (Offerman et al., 2013).

Vaccination is considered the cornerstone to control fowl pox infection especially in laying hens. A long time ago, FP was not affecting commercial poultry farms obviously in Egypt. Since 2011, the number of identified new infections was increased in backyard reared chickens (Abdallah and Hassanin, 2013, Susan et al., 2014; Ali et al., 2015 and Abdo et al., 2017). The objective of the present study is to provide an antigenic and molecular identification of Egyptian pox virus isolated from infected laying hen farms in 2017 to contribute to the preparation of vaccines form local strains against FP disease in chicken.

\section{Sample collection}

\section{MATERIALS AND METHODS}

A total of 4 suspected samples were collected from backyard naturally infected laying hens (mixed breed) aged about 16 weeks in some villages in ElSharkia governorate, northern part of the Nile Delta of Egypt, from January to November 2017. These diseased hens were suffering from skin lesions on eyelids and beak, with a decrease in egg production. Nodular lesions at face region were cut from 105 days old mixed breed backyard hens using a sterile blade and placed in sterile tubes with $1.5 \mathrm{ml}$ sterile transport medium. Samples were sent to Pox Research and vaccine production department, VSVRI, Cairo, Egypt and stored at $-20^{\circ} \mathrm{C}$ as mentioned by (OIE2018).

\section{Samples preparation}

Using sterile mortar and pestle, scab collected from affected hens were grounded in phosphatebuffered saline (PBS) to obtain 10\% suspension, that was centrifuged at $1500 \mathrm{rpm}$ for $15 \mathrm{~min}$ and treated with a mixture of Penicillin (10000 units/ml of supernatant) and streptomycin $(10 \mathrm{mg} / \mathrm{ml}$ of supernatant) for 1 hour at $37^{\circ} \mathrm{C}$ (OIE2018).

\section{FPV isolation, propagation and titration in SPF- ECE}

The virus isolation, propagation, and titration were performed following the procedure mentioned by (OIE 2018) using two hundred 9-11 day old (SPFECE) kindly supplied by Qum Oshim SPF farm at ElFayoum governorate, Egypt. The sample $(0.2 \mathrm{ml})$ was initially inoculated onto the CAM of SPF 10-day-old developing chicken embryos, as mentioned by (Gilhare et al., 2015). The embryos were incubated at $37^{\circ} \mathrm{C}$ and checked daily for mortality five days post-inoculation (PI), then the harvested CAM was examined for pock lesion. Standard control vaccine strain was obtained gratefully by Pox Research and vaccine production department VSVRI, Cairo, Egypt. Titer calculation was done using the statistical method described by (Reed and Meunch 1938).

\section{Preparation of CEF cell culture}

Chicken embryo fibroblast cell cultures were prepared according to the method described by (Gilhare et al., 2015 and Nesma 2016) using ten days old chicken embryos. It was used for the primary propagation of the isolated virus.

\section{Adaptation, propagation and titration of FPV isolate in chicken embryo fibroblast cells (CEF). \\ It was done till the $4^{\text {th }}$ passage according to (Gilhare et al., 2015 and Nesma 2016).}

\section{Virus neutralization test}

To confirm that the propagated viruses belong to FPV, the neutralization test was applied on isolated viruses on SPF-ECE and the adapted virus on CEF as described by (OIE, 2018) using specific hyperimmune serum against PPV and FPV that were kindly supplied by the Pox vaccines Research department, VSVRI, Egypt. The virus titer (VT) and the serum virus titer (SVT) were calculated using the statistical method described by (Reed and Meunch 1938). The neutralization index (NI) was subsequently calculated as follows: NI $=$ VT-SVT according to (pilchard $\boldsymbol{e t} \boldsymbol{a l}$., 1962).

\section{DNA extraction and PCR amplification}

Genomic DNA Mini kit (Qiagen, Cat. No. GB100) was used for DNA extraction according to the manufacturer's instructions from skin lesion as well as 
pock lesions of propagated viruses inoculated on CAM of SPF-ECE and from CEF propagated virus. The amplification of $578 \mathrm{bp}$ of the P4b gene ( $f p v 167$ gene) was performed by using primers: Forward M2925: 5'- CAGCAGGTGCTAAACAACAA -3' and Reverse M2926: 5'CGGTAGCTTAACGCCGAATA -3' according to (Huw Lee and Hwa Lee 1997). The initial denaturation was done at $94^{\circ} \mathrm{C}$ for $5 \mathrm{~min}$ followed by 35 cycles of denaturation at $94^{\circ} \mathrm{C}$ for $1 \mathrm{~min}$, annealing at $60^{\circ} \mathrm{C}$ for $1 \mathrm{~min}, 72^{\circ} \mathrm{C}$ for $1 \mathrm{~min}$ then final extension at $72^{\circ} \mathrm{C}$ for $2 \mathrm{~min}$. The amplification of the FPV 140 gene was tried with two different primer sets. The first was reported previously by (Jarmin et al., 2006) M2904: 5'-GAAGTAGAGTTACGGTTC-3', M2912: 5'-GGTGATCCATTTCCATTTC-3' for amplification of $1800 \mathrm{bp}$ while the second set was used for amplification of $1150 \mathrm{bp}$ of $f p v 140$ genes using forward env1: 5'GGTTATTTCGTATGATTATGTT3 ', Reverse env2:5'-AAAAGATCAAGGAACTATAC$3^{\prime}$ with cycling parameters included: $95^{\circ} \mathrm{C}$ for $5 \mathrm{~min}$, 30 cycles of $94^{\circ} \mathrm{C}$ for $1 \mathrm{~min}, 48^{\circ} \mathrm{C}$ for $30 \mathrm{~s}$, and $72^{\circ} \mathrm{C}$ for $1 \mathrm{~min}$ and a final extension at $72^{\circ} \mathrm{C}$ for $7 \mathrm{~min}$ according to (Li et al., 2012). Negative PCR controls (Un inoculated CAM) were included with each reaction. PCR products were analyzed by $1 \%$ agarose gel electrophoresis with $1 \mathrm{~kb}$ DNA ladder (Fermentas). The selected PCR products were purified and sent for sequence analysis.

\section{Sequence and phylogenetic analysis}

PCR products of $\mathrm{P} 4 \mathrm{~b}$ gene $(578 \mathrm{bp})$ of commercial FPV vaccine, (Sharkia2017/VSVRI) isolate from skin nodule and its passage on ECE as well as PCR product of $f p v 140$ gene $(1150 \mathrm{bp})$ of (Sharkia2017/VSVRI) isolate from $4^{\text {th }}$ passaged on ECE were purified by QIA quick PCR Product extraction kit (Qiagen) and sent for sequence analysis using (GATC Company, Germany) by using ABI 3730x1 DNA sequencer. Multiple alignment and phylogenetic analyses were done using Bioedit and MEGA 6 software compared with other isolates (Table 1).

\section{RESULTS}

\section{Clinical and Gross findings}

The diseased birds were suffering from nodular lesions on the eye, nostrils and non-feather area. The recorded mortality rates were up to $6 \%$ as shown in Fig. (1) with no symptoms for diphtheritic and systemic forms. Nodular lesions variable in size were found in the skin of sick birds suffered from depressing, anorexia, dull, weight loss and decreased egg production. The nodular facial lesion was shown, especially the eye region on diseased laying hen.

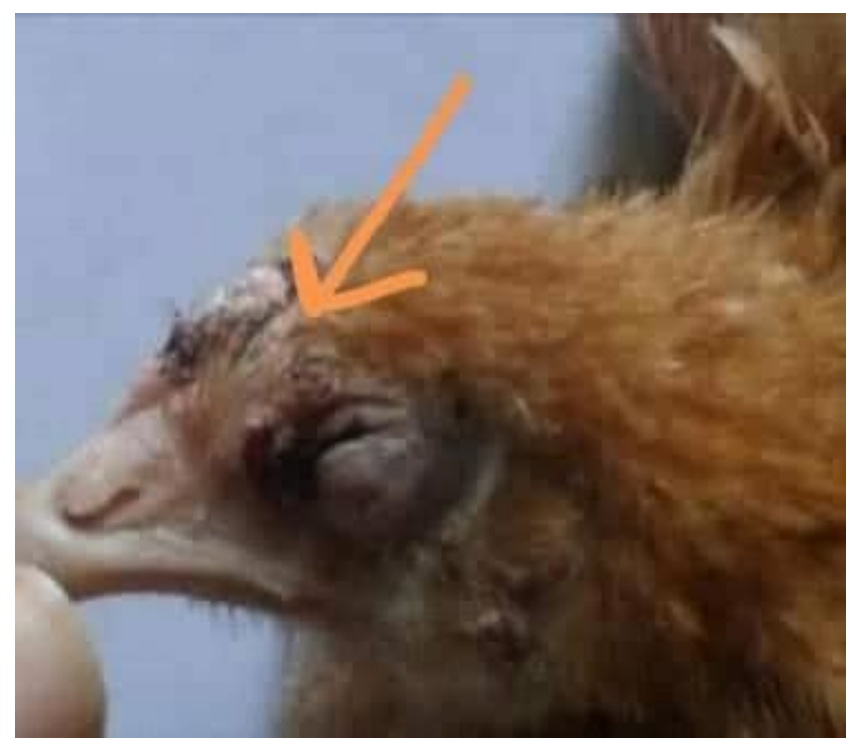

Fig.1: Affected laying hens showing nodular lesion on face.

\section{Virus isolation, propagation and titration in SPF- ECE}

Characteristic pock lesions were observed in inoculated CAM of SPF ECE with FPV isolated from skin lesions collected and processed from suspected hens, in the $2^{\text {nd }}$ passage, the CAM became edematous, opaque and thick as shown in Fig. (2). It became round shape opaque small pock lesion at the $3^{\text {rd }}$ passage as illustrated in Fig. (3). In the $4^{\text {th }}$ passage, a raised opaque necrosed area, round in the shape of $3-5 \mathrm{~mm}$ in diameter, was developed with a center slightly raised than the periphery. Congestion and sometimes small hemorrhagic areas were also noticed as shown in Fig. (4). The pock lesions formed by control positive vaccine strain were grayish-white and slightly raised with sizes ranging from $0.7 \mathrm{~mm}$ to $2.5 \mathrm{~mm}$ in diameter Fig. (5) and raised somewhat central area than the periphery. The virus titer of isolated FPV reached 4.0

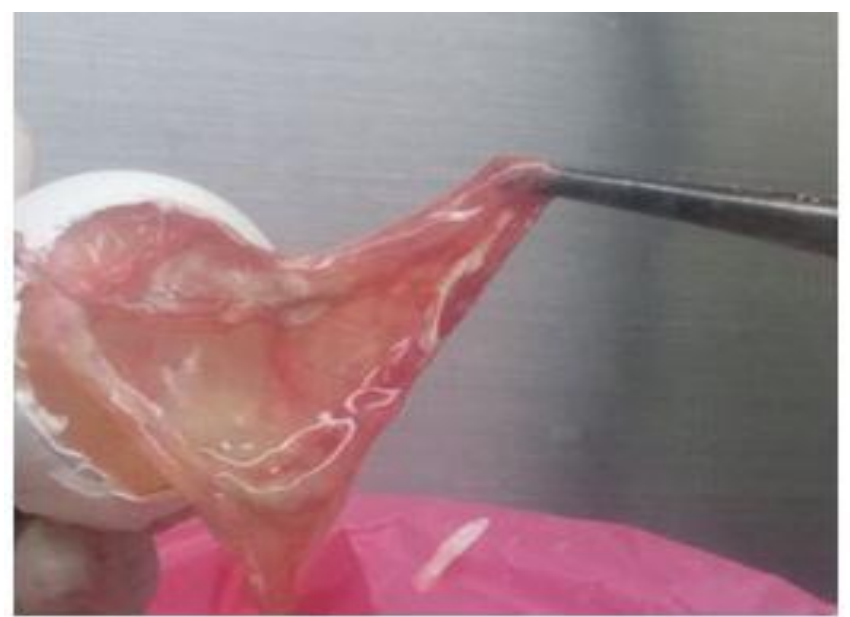

$\log _{10} \mathrm{EID}_{50} / \mathrm{ml}$ at passage No. 4 as shown in table (2).

Fig. 2: Opaque, edematous and thick CAM of $2^{\text {nd }}$ passage of isolated FPV 


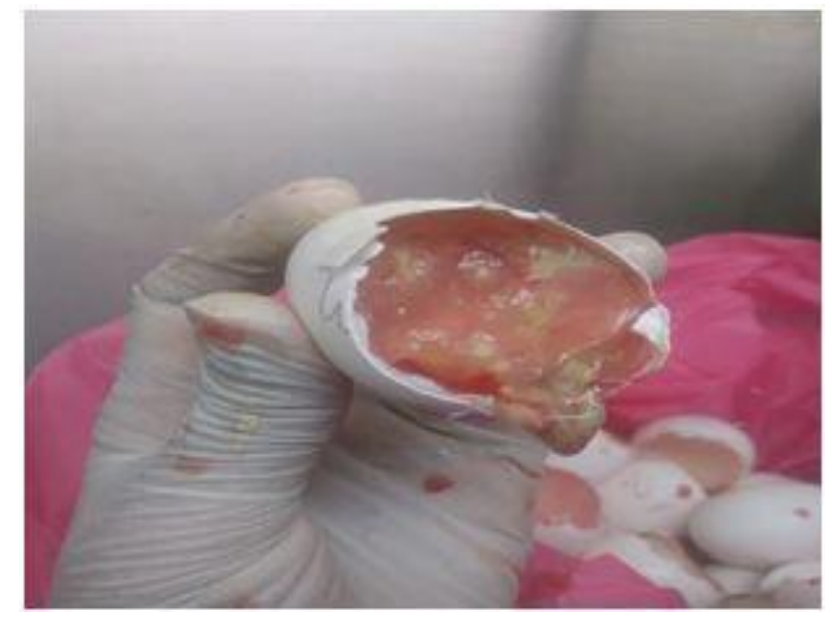

Fig.3: Focal white opaque small pock lesions of FPV isolate.

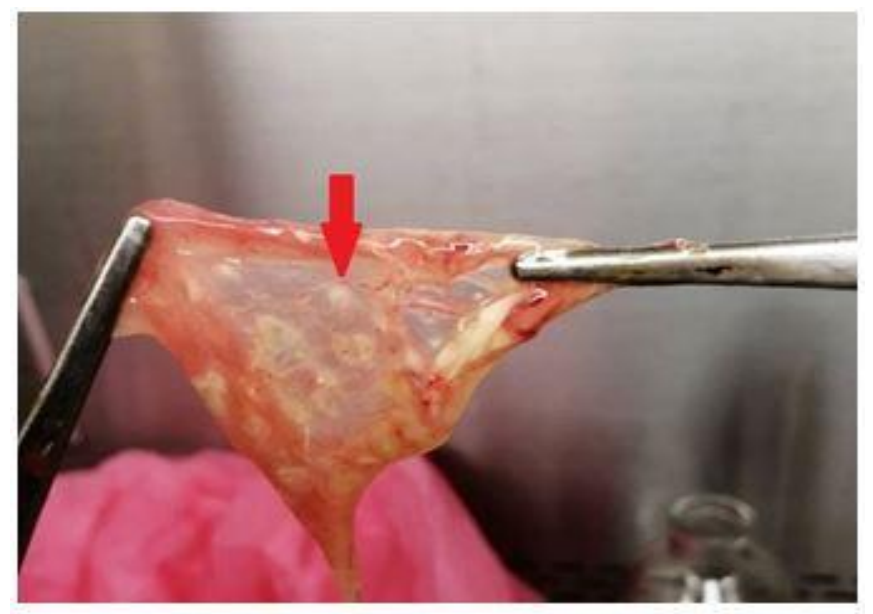

Fig.4: $4^{\text {th }}$ passage showed round shape opaque raised necrosed area of 3-5 $\mathrm{mm}$ in diameter were developed with Central area is slightly raised than the periphery.

Table 1:Multiple alignment accession number obtained from Genbank

\begin{tabular}{|c|c|c|c|c|}
\hline \multirow{2}{*}{ Virus name } & \multirow{2}{*}{ Host } & \multirow{2}{*}{ Type } & \multicolumn{2}{|c|}{ Accession number } \\
\hline & & & fpv140 & $f p v 167$ \\
\hline Nobilis Variole W & Chicken & A1 & AM071394 & AM050379 \\
\hline GB 134/01 & Turkey & A1 & & AY530304 \\
\hline Peekham 19/11/75 & Pigeon & $\mathrm{A} 2$ & AM071389 & AM050385 \\
\hline TP-2 & Pigeon & $\mathrm{A} 2$ & & AY530303 \\
\hline Fort Dodge & Canary & B1 & & AM050384 \\
\hline $1381 / 96$ & Falcon & A3 & AM071515 & AM050376 \\
\hline GB362-02 & Falcon & A3 & & AY530306 \\
\hline $353 / 87$ & $\begin{array}{l}\text { Black-browed } \\
\text { albatross }\end{array}$ & A3 & AM071388 & AM050392 \\
\hline 2009/India/06 & Sparrow & A1 & - & HM481407 \\
\hline GB 320/02 & Sparrow & B1 & - & AY530308 \\
\hline Fowl pox HP-B & Chicken & A1 & - & AY530302 \\
\hline $\begin{array}{l}\text { Fowl pox Mild (Websters; } \\
\text { Fort Dodge) }\end{array}$ & Chicken & A1 & - & AM050378 \\
\hline Maryland (USA) 1984 & European starling & B2 & - & KC018063 \\
\hline Hawaii $\uparrow$ (USA) 1996 & Canary & B1 & - & KC018014 \\
\hline Hungary & Rock dove & $\mathrm{A} 2$ & - & KC017969 \\
\hline Hungary 2003 & Domestic fowl & A1 & - & KC017960 \\
\hline Elsharqyia_FWPV4 & Chicken & A1 & JX464825 & JX464821 \\
\hline FWPV-SD15-67 & Chicken & A1 & & MH734528 \\
\hline $903731 / 5 / 66 / 23$ & Sparrow & $\mathrm{B}$ & AM071510 & - \\
\hline Egypt_FWPV_CH25 & Chicken & A1 & MH720328 & - \\
\hline Egypt_FWPV_PG43 & pigeon & - & MH720332 & - \\
\hline PA10-13385 & Chicken & - & FR852588 & - \\
\hline
\end{tabular}


Table 2: Fowl pox virus titer on SPF -ECE

\begin{tabular}{|cc|}
\hline $\begin{array}{c}\text { Virus titer } \log _{10} \\
\text { EID50/ml }\end{array}$ & No. of passage \\
\hline 2.5 & $1^{\text {st }}$ passage \\
\hline 3.0 & $2^{\text {nd }}$ passage \\
\hline 3.5 & $3^{\text {rd }}$ passage \\
\hline 4.0 & $4^{\text {th }}$ passage \\
\hline
\end{tabular}

Fig. 5: Grayish white raised pock lesion of inoculated CAM with a vaccinal strain of FP on SPF -ECE

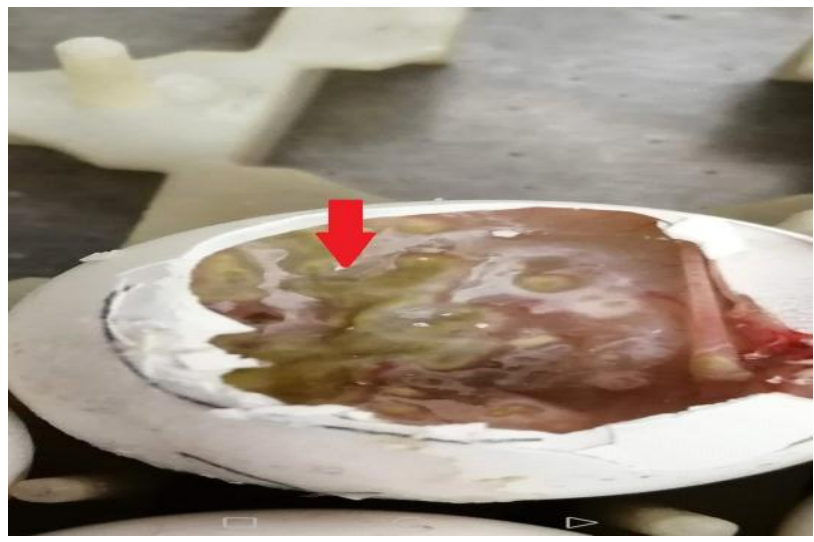

Table 3: Results of VNT for FPV isolated and propagated on ECE and CEF

\begin{tabular}{|c|c|c|c|c|c|}
\hline \multirow{2}{*}{$\begin{array}{l}\text { NI with } \\
\text { PHIS }\end{array}$} & \multirow{2}{*}{$\begin{array}{l}\text { NI with } \\
\text { FPHIS }\end{array}$} & $\begin{array}{l}\text { VST with } \\
\text { PPHIS }\end{array}$ & $\begin{array}{l}\text { VST with } \\
\text { FPHIS }\end{array}$ & $\begin{array}{l}\text { Virus } \\
\text { titer }\end{array}$ & \multirow[t]{2}{*}{ Isolated virus } \\
\hline & & \multicolumn{3}{|c|}{ Titer expressed as $\log _{10} \mathrm{EID}_{50} / \mathrm{ml}$} & \\
\hline 2.0 & 2.5 & 2.0 & 1.5 & 4.0 & FPV isolate \\
\hline \multirow{2}{*}{$\begin{array}{l}\text { NI with } \\
\text { FHIS }\end{array}$} & \multirow{2}{*}{$\begin{array}{l}\text { NI with } \\
\text { PPHIS }\end{array}$} & $\begin{array}{l}\text { VST with } \\
\text { PPHIS }\end{array}$ & $\begin{array}{l}\text { VST with } \\
\text { FPHIS }\end{array}$ & $\begin{array}{l}\text { Virus } \\
\text { titer }\end{array}$ & \multirow[t]{2}{*}{ Isolated virus } \\
\hline & & Titer expre & as $\log _{10} \mathrm{~T}$ & )$_{50} / \mathrm{ml}$. & \\
\hline 1.5 & 2.0 & 2.0 & 1.5 & 3.5 & FPV isolate \\
\hline
\end{tabular}

VNT: virus neutralization test ECE: embryonated chicken egg $\quad$ CEF: Chicken embryo fibroblast

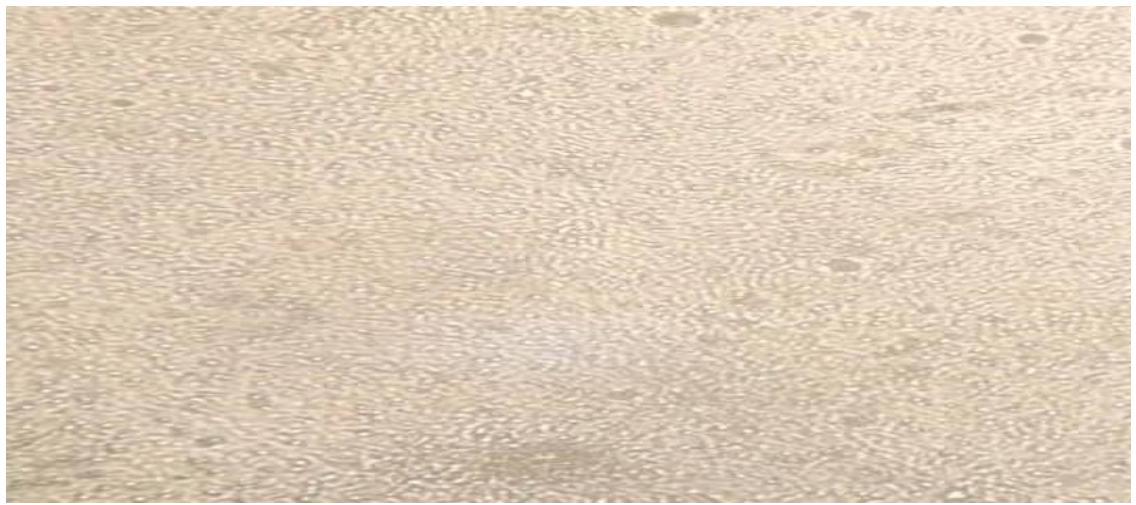

Fig. 6: Normal CEF showing healthy shiny cells.

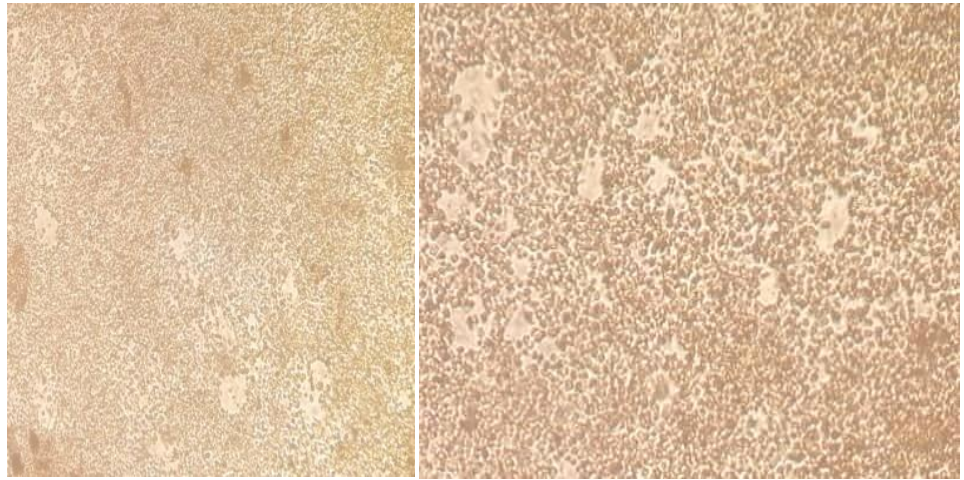

Fig. 7
Fig. 8

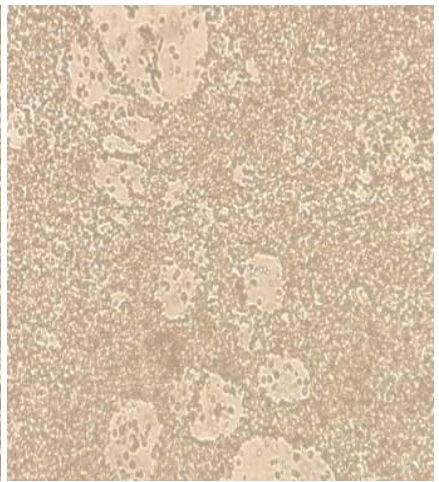

Fig. 9

Figs. (7,8 \&9) Different stages of FP CPE in CEF showing cell rounding and detachment with the appearance of vacuoles 


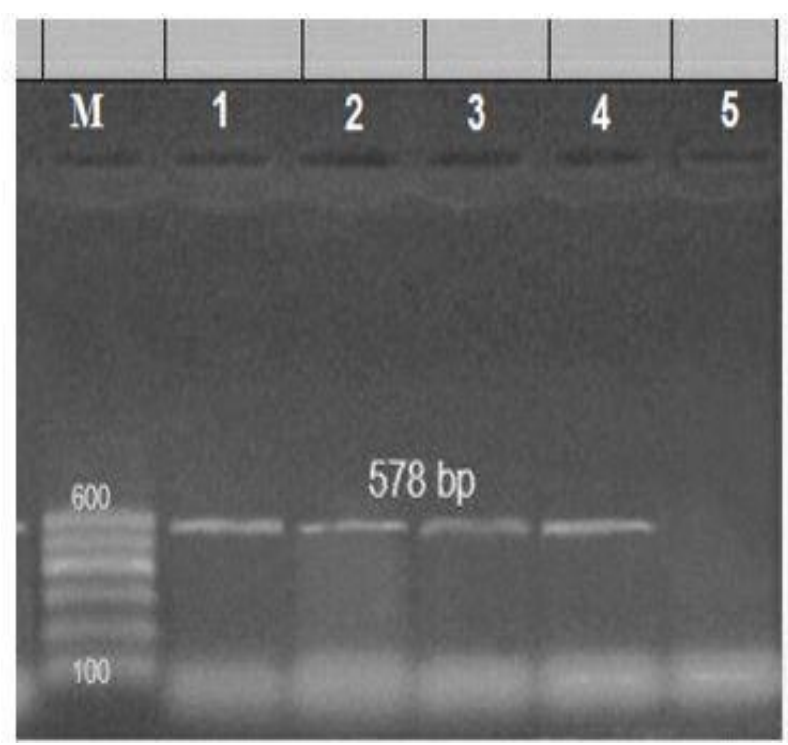

Fig. 10: PCR amplified products for $\mathrm{p} 4 \mathrm{~b}$ gene were compared with 100 bp DNA ladder. All tested samples showed a positive band at $578 \mathrm{bp}$ (Lanes 1-3) as well as the commercial Fowl pox virus vaccine as a positive control (Lane 4). The negative control (Un inoculated CAM) showed no amplification (Lane 5).

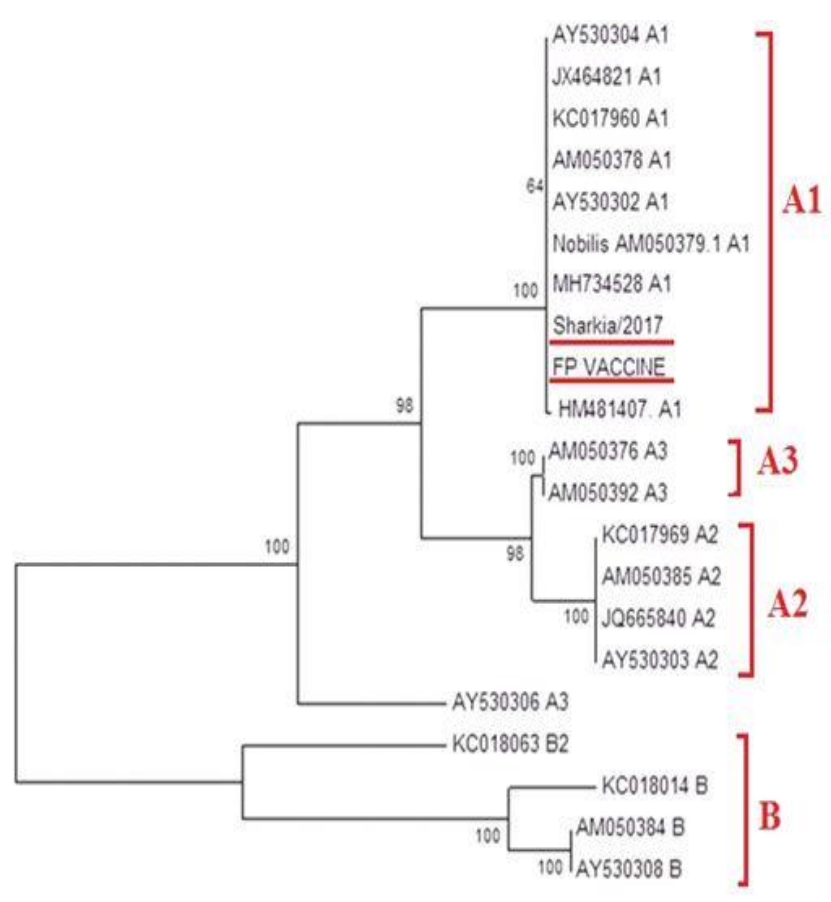

Fig. 12: Phylogenetic tree of Avipox viruses based on the nucleotide sequence of P4b gene (fpv167) using Maximum Likelihood analysis with 1000 bootstrap replication.

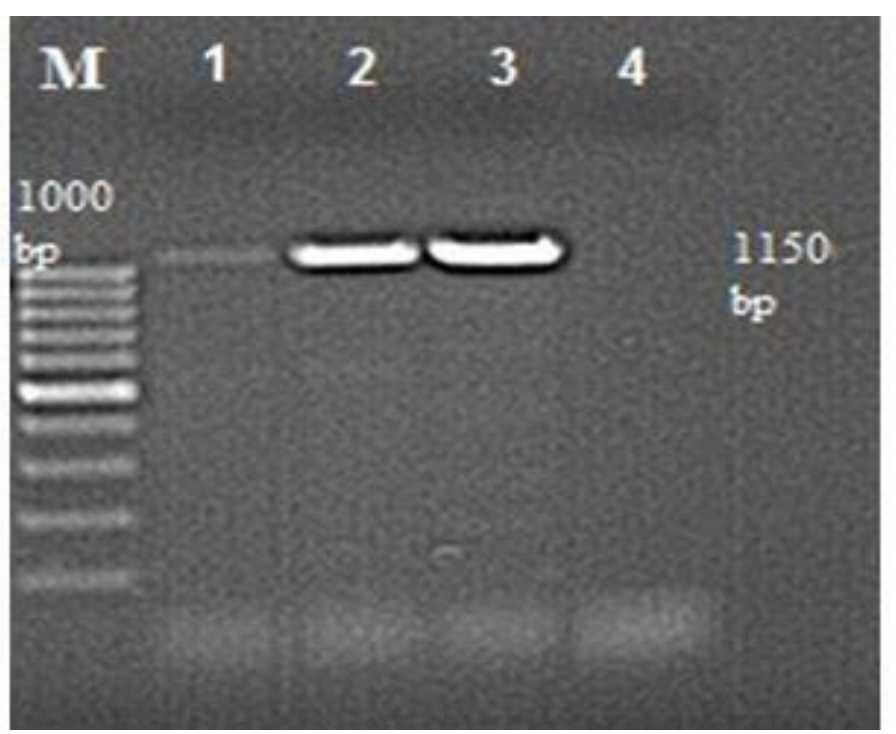

Fig. 11: PCR amplification for fpvl40 gene (1150 bp). Lane (1) Sharkia2017 cutaneous lesions (skin lesion), Lane (2) $4^{\text {th }}$ passage of the propagated isolated virus on ECE, Lane (3) The commercial Fowl pox virus vaccine, Lane (4) negative control (Un inoculated CAM) showing no amplification.

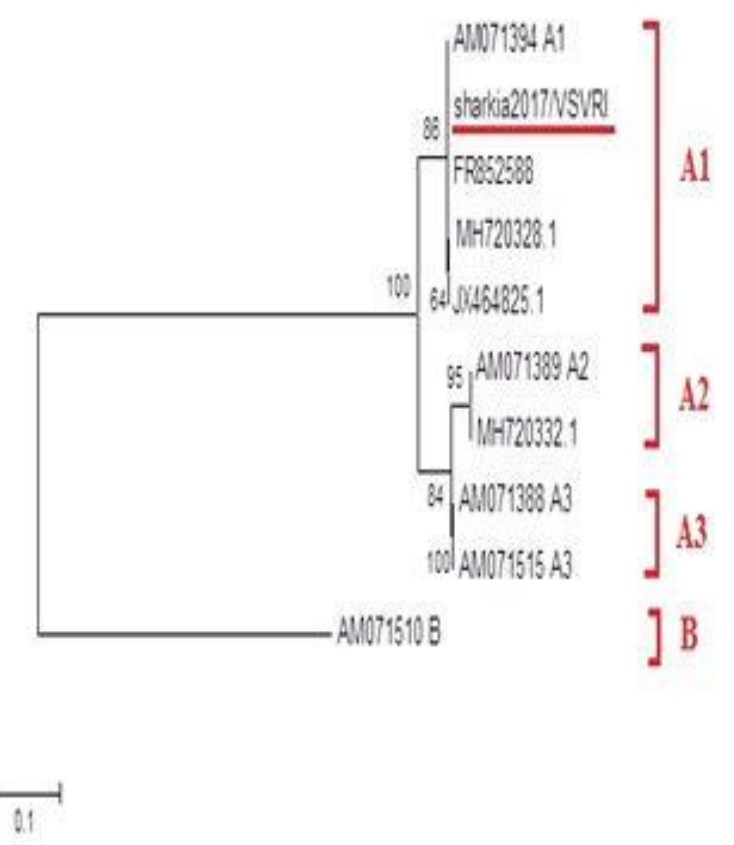

Fig.13: Phylogenetic tree of Avipox viruses based on the nucleotide sequence of $f p v 140$ gene using Maximum Likelihood analysis. 
Adaptation, propagation and titration of isolated FPV on CEF

In the $3^{\text {rd }}$ passage, the CEF cell culture showed cell aggregation that rapidly progressed and appeared as floating cells 3 days post-inoculation as shown in Fig. (7). After the $4^{\text {th }}$ day, rounding and degeneration of cells and seem like a bunch of grapes as shown in Fig. (8). After the $5^{\text {th }}$ day massive detachments of cells were observed and the remaining cells became elongated. Syncytia formation appeared as shown in Fig. (9), while the uninfected controls showed no changes as shown in Fig. (6). The titer of propagated FPV on CEF cell culture increased gradually till the constant highest titer (3.5 $\log _{10}$ $\mathrm{TCID}_{50} / \mathrm{ml}$ ) at the $4^{\text {th }}$ passage.

\section{Virus neutralization test on ECE and CEF}

Virus neutralization test was carried on the propagated FPV on ECE and CEF using standard pigeon pox hyperimmune sera (PPHS) and fowl pox hyperimmune sera (FPHS) resulting in a reduction in virus titer with $2.0 \mathrm{NI}$ and $1.5 \mathrm{NI}$ respectively as shown in table (3).

\section{Polymerase chain reaction (PCR) for $\mathrm{P4b}$ and fpv140 gene}

PCR amplification was used for the detection of Avipoxvirus-specific DNA (P4b gene-578 bp). DNA extracted from cutaneous lesions collected from infected hens (Fig.10, lane1) and $4^{\text {th }}$ passage of the propagated isolated virus on ECE (lane 2) and CEF (lane 3) showing positive results as well as commercial fowl pox virus vaccine positive control (lane 4) as indicated by PCR fragment of approximately $578 \mathrm{bp}$, meanwhile, the absence of this band in the negative control (lane 5) as shown in Fig. (10). fpv140 gene was amplified using two sets of primers to differentiate between Fowl pox like viruses and Canary pox like viruses. According to Jarmin et al. (2006), the first set failed to show any amplification in all tested samples. Meanwhile, the second set of primers according to (Li et al., 2012), was used for amplifying $1150 \mathrm{bp}$ of $f p v 140$ gene. All tested samples were positive as shown in Fig. (11).

\section{Sequence and phylogenetic analysis of $\mathrm{P} 4 \mathrm{~b}$ gene}

Sequence analysis of the field isolate (Sharkia2017/VSVRI) PCR product revealed 523- bp and 1008 bp for P4b and fpv140 genes, respectively. The P4b gene of (Sharkia2017/VSVRI) isolates from skin nodule, from $4^{\text {th }}$ passage on ECE and from commercial FPV vaccine were submitted to GenBank with accession number (MH035836), (MN542415) and (MN708968) respectively. Fpv140 gene for $4^{\text {th }}$ passage on ECE of Sharkia2017/VSVRI was submitted with accession number (MN708967). The three sequences obtained from (Sharkia2017/VSVRI) either skin nodule or pock lesion on CAM or commercial Fowl pox virus vaccine all showed $100 \%$ identity on the nucleotide level. The obtained sequence was aligned with 20 known Avipox viruses representing Clade A1, A2, A3, B1 and B2 from different bird species representing the $\mathrm{P} 4 \mathrm{~b}$ gene as well as fpv140 gene (Table 1).

Phylogenetic analysis for the $\mathrm{P} 4 \mathrm{~b}$ gene (fpv167) encoding for core protein was performed with the maximum likelihood method for nucleotide sequences (Fig. 1). The phylogenetic tree showed two major branches representing clade A (Fowl pox like viruses) and clade B (Canary pox like viruses). Clade A was subdivided into 3 subclades A1, A2, and A3, while clade B was divided into two subclades B1 and B2. The Egyptian isolate Sharkia2017/VSVRI was clustered in subclade A1 that included FPV from chicken with $100 \%$ identity between them as calculated with MegAlign software (Lasergene).

Phylogenetic analysis for fpv140 gene encoding for envelope protein was performed with the maximum likelihood method for nucleotide sequences (Fig. 2). The tree was branched into two major clades: A and B where Sharkia2017/VSVRI belonged to Clade A and clustered in subclade A1 with other Fowl pox viruses showing high nucleotide identity (99.7$100 \%)$.

\section{DISCISSION}

In the current study, samples were collected from affected layer chickens showing cutaneous form Fig. (1) with no symptoms for diphtheritic and systemic forms. Nodules in the skin of sick birds were variable in size with the same clinical signs as described previously by (Biswas et al., 2011 and Gilhare et al., 2015) who reported FPV infection in unvaccinated backyard chickens with no mortality.

The local isolate was isolated on CAM showing the characteristic pock lesions for FPV after the $3^{\text {rd }}$ passage as distinct small size pock lesion with as shown in Fig.s ( 3 and 4) similar to the pock lesion produced by vaccine FP strain as shown in Fig. (5) which is more larger with some greenish coloration. The distinguished pock lesion of isolated FPV is constant in diameter and can be used for a neutralization test with a titer of $4 \log _{10} \mathrm{EID}_{50} / \mathrm{ml}$ at the $4^{\text {th }}$ passage. These results agree with those described by (Abdallah and Hassanin 2013, Masola et al., 2014, and Gilhare et al., 2015) who also recorded that FPV pock lesion is characterized by its smaller size and whitish coloration than other pock lesions of APVs. 
Isolated FPV was propagated on CEF as clear CPE appeared after the 3rd passage reaching a virus titer of $3.5 \log _{10} \mathrm{TCID}_{50} / \mathrm{ml}$ at $4^{\text {th }}$ passage and the inoculated cell culture showed aggregated cells and floating cells at $3^{\text {rd }}$ day PI. After the $6^{\text {th }}$ day PI, massive detachment of cells was observed as shown in (Fig.s 7, 8, and 9). (Yadav et al., 2007 and Galihare et al., 2015) also mentioned that FPV could be adapted and propagated in CEF cell culture and capable of producing characteristic CPE with a gradual appearance by the 3rd passage as rounded and degenerated cells with vacuolation and cell aggregations with grab formation.

For identification of isolated propagated FPV, VNT was performed in ECE and CEF as shown in (Table 3) where reduction of the titer of the isolated FPV using standard anti- pigeon pox hyperimmune sera (PPHIS) was 1.5 and $2.0 \mathrm{NI}$ when used homologues anti-fowl pox hyperimmune sera (FPHIS) were used which indicated the high relationship for the isolated FPV to FPV than PPV. Similar results obtained by (Sumaya 2005 and Alehegn et al., 2014). Molecular characterization of the tested virus in this study confirmed that it is related to the avipox virus by PCR amplification of 578 bp of P4b (fpv167) gene Fig. (10) which is highly conserved region among Avipox viruses (Jarmin et al., 2006). It is usually used for comparative genetic analysis and as the most sensitive technique for the detection and routine diagnosis of avian poxviruses (Manarolla $\boldsymbol{e t}$ al., 2010 and Fasaei et al., 2013).

Sequence and phylogenetic analysis of the P4b gene (fpv167) could classify avipox viruses according to Jarmin et al., 2006 and Manarolla et al., 2010 into three major clades: A (Fowlpox-like viruses), B (Canarypox-like viruses), and C (Psittacinepox-like viruses). Clade $\mathrm{A}$ is further subdivided into subclade A1 (Fowlpox virus), A2 (Turkeypox virus), A3, and A4, whereas clade B is subdivided into subclade B1 (Canarypox virus) and B2 (Straling pox virus). The phylogenetic analysis of the $f p v 140$ gene could discriminate between these different viruses: two major clades: A and B. Clade A is furthermore subdivided into subclade A1 (Fowlpox virus), A2 (TKPV), A3 (Falcon and Albatross pox Virus), and A4 (PGPV), whereas clade B is a Canarypox virus (Jarmin et al., 2006, Carulei et al., 2009 and Manarolla et al., 2010).

Sequence analysis of field isolate (Sharkia2017/VSVRI) and its passages on ECE $\left(4^{\text {th }}\right.$ passage) or CEF showed $100 \%$ nucleotide similarity on the level of $\mathrm{P} 4 \mathrm{~b}$ gene confirming that $\mathrm{P} 4 \mathrm{~b}$ is highly conserved in Avipox viruses and not affected by passaging in different hosts. Also, sequence analysis of the P4b gene (Sharkia2017/VSVRI) showed that it belongs to Fowl pox viruses with $99.8 \%$ - $100 \%$ identity. Furthermore, phylogenetic analysis Fig. (12) could locate the field isolate (Sharkia2017/VSVRI) within Fowl pox like viruses, sub-clade A1. Similar results were obtained by (Abdallah and Hassanin 2013) who studied FPV in chicken and pigeon in Egypt.

Molecular characterization was also confirmed by amplification of 1150 bp of fpv140 gene - the envelope protein- which is highly conserved across fowlpox virus sequences, very important in genotyping of fowlpox viruses (Li et al., 2012) and allowed the differentiation between fowlpox viruses and canary pox viruses (Jarmin et al., 2006). The fpv140 gene sequence and phylogenetic analysis results of (Sharkia2017/VSVRI) isolate confirmed that it was highly conserved and locate it within Fowl pox viruses clade in the phylogenetic tree (Clade A1) Fig. (13).

\section{CONCLUSIONS}

In conclusion, the present study paved the way for rapid identification and characterization of the isolated FPV in the unavailability of reference hyperimmune serum. Further immunological and cell culture propagation is needed to facilitate the preparation of attenuated tissue culture vaccine from the locally isolated strain.

\section{REFERENCES}

ABDALLAH F M and HASSANIN O. 2013. Detection and molecular characterization of avipoxviruses isolated from different avian species in Egypt. Virus Genes 46:63-70.

ABDO W, MAGOUZ A, El-KHAYAT F and KAMAL T. 2017. Acute outbreak of co-Infection of fowl pox and infectious laryngotracheitis viruses in chicken in Egypt.

Pak Vet J, 37(3):321-325.

ALEHEGN E, CHANIE M ANDand MENGESHA D. 2014. A Systematic Review of Serological and Clinicopathological Features and Associated Risk Factors of Avian Pox. Br J Poult Sci 3: 78-87.

ALI A A, SHIMAA M G, ASHRAF M F AND AMAL A M. 2015. Detection of Avian Poxvirus in an Egyptian goose. Global Animal Science Journal-GASJ 2(1):12151218.

ANDREW M Q KING, MICHAEL J ADAMS, Eric B CARSTENS, and EILIOT J LEFKOWIT Z. 2012. Virus Taxonomy: Classification and Nomenclature of Viruses: Ninth Report of the International Committee on Taxonomy of Viruses. International Union of Microbiological Societies Virology Division.Academic Press, London; Waltham. Published by Elsevier Inc. age 192-300.

BISWAS S K, JANA C, CHAND K, REHMAN W, and MONDAL B. 2011. Detection of fowl poxvirus integrated with reticuloendotheliosis virus sequences 
from an outbreak in backyard chickens in India. Vet Ital., 47: 147-153.

CARULEI O, DOUGLASS N AND WILLIAMSON AL. 2009. Phylogenetic analysis of three genes of the Penguinpox virus corresponding to Vaccinia virus G8R (VLTF-1), A3L (P4b) and H3L reveals that it is most closely related to Turkeypox virus, Ostrichpox virus and Pigeonpox virus. Virol, J., 2009, 6: 5210.1186/1743-422X-6-52.

CLAYDEN E C., 1971. Practical Staining $5^{\text {th }}$ edition. Edinburgh and Loudin, 7: 244-246.

DAS P, JOARDAR SN, SAMANTA I, DAS PK, JANA C, ISORE DP and SADHUKHAN TK. 2013. Isolation and molecular confirmation of Avipoxvirus in backyard chicken in West Bengal. Indian J. Comp. Microbiol. Immunol. Infect. Dis. (3).pp: 154-156.

FASAEI N, MADADGAR B, LANGEROODI OA and GHAFARI M. 2014. Molecular detection and phylogenetic analysis of Avipoxvirus strains isolated from different bird species. Iranian J Vet Res 2014; 15(1): 40-4.

GILHARE VR, HIRPURKAR SD, KUMAR A, NAIK SK and SAHU T. 2015. Pock forming ability of fowl pox virus isolated from layer chicken and its adaptation in chicken embryo fibroblast cell culture. Vet World.;8 (3):245-250.

HUW LEE L and HWA LEE K. 1997. Application of the polymerase chain reaction for the diagnosis of fowl poxvirus infection. J.Virol. Methods. 1997 Jan; 63(12):113-9.

JARMIN R, MANVELL RE, GOUGH SM, LAIDLAW MA AND SKINNER 2006. Avipoxvirus phylogenetics identification of a PCR length polymorphism that discriminates between the two major clades. J. Gen. Virol. 87, 2191-2201.

LI G, HONG Q, REN Y, LILLEHOJ H, HE C AND REN X. 2012. Development of FPV140 antigenspecific ELISA differentiating fowlpox virus isolates from all other viral pathogens of avian origin. Poult Sci 91: 2507-2511.

MASOLA SN, MZULA A, TUNTUFYE HN, KASANGA CJ AND WAMBURA PN. 2014. Isolation and Molecular Biological Characterization of Fowl pox Virus from Specimen of cutaneous nodular Lesions from Chickens in Several regions of Tanzania. British Microbiology Research Journal, 4 (7): 759-771.

How to cite this article:

Aboul Soud, E. A; Ayatollah, I. Ibrahim., Abd El-Moaty, D.A.M., Kafafy M. H and Abass. A. M.2020.Antigenic And Genomic Characterization of Local Fowlpox Virus Isolate in 2017. Journal of Applied Veterinar Sciences, 5(3): 31 - 39.

DOI: HTTPS://DX.DOI.ORG/10.21608/JAVS.2020.98319
MANAROLLA G, PISONI G, SIRONI G AND RAMPIN T. 2010. Molecular biological characterization of avian poxvirus strains isolated from different avian species. Vet Microbiol, 140: 1-8.

NESMA M H. 2016. Preparation of fowl pox vaccine on BGM cell line. MSV Virology, Banha University, Egypt

OFFICE INTERNATIONAL DES EPIZOOTIC (OIE) 2018. Recommended Diagnostic Technique and Requirements for biological products, Volume 1 (chapter 3.3.10. pp. 907-913).

OFFERMAN K, CARULEI O, GOUS T, DOUGLASS N AND WILLIAMSON AL. 2013. Phylogenetic and histological variation in avipoxviruses isolated in South Africa. J Gen Virol, 94:2338-2351.

PILCHARD EI, HANSON LE AND ALBERTS JO. 1962. Fowlpox Virus Neutralization Antibody and Viremia in Turkeys. Avian Diseases, Vol. 6, No. 4, pp. 396-402

REED LJ, AND MUNECH H. 1938. A simple method of estimating fifty percent endpoints. Am. J. Hyg, 27:493-497.

SAWALE GK, ROSHINI S, BULBULE NV, CHAWAK MM AND KINGE GS. 2012. Pathology of fowl pox in chickens. Indian J. Vet. Pathol. 36 (1): 110-111.

SUMAYA KHALGALI MOHAMED KHOGALI. (2005): Pathogenic antigenic and serologic relationship between fowl pox, pigeon pox and canary pox viruses M.V.Sc., University of Khartoum.

SUSAN S E, AWAAD MH AND SOLIMAN YA. 2014. Molecular identification of local field isolated fowl pox virus strain from Giza governorate of Egypt. Veterinary world Vol. (7) PP: 66-71.

YADAV S, DASH BB, KATARIA JM, DHAMA K, GUPTA SK AND RAHUL S. 2007. Pathogenicity study of different avipox viruses in embryonated chicken eggs and cell cultures. Indian J. Vet. Pathol., 31(1): 17-20. 